OPEN ACCESS

Edited by:

Margiana Petersen-Rockney, University of California, Berkeley, United States

Reviewed by: Emily A. Martin, Julius Maximilian University of Würzburg, Germany Dana James, University of British Columbia, Canada Anne Elise Stratton, University of Michigan, United States

*Correspondence: David A. Mortensen david.mortensen@unh.edu

tThese authors have contributed equally to this work

Specialty section

This article was submitted to Agroecology and Ecosystem Services, a section of the journal Frontiers in Sustainable Food Systems

Received: 20 May 2020 Accepted: 28 September 2020 Published: 10 November 2020

Citation:

Mortensen DA and Smith RG (2020) Confronting Barriers to Cropping System Diversification. Front. Sustain. Food Syst. 4:564197. doi: 10.3389/fsufs.2020.564197

\section{Confronting Barriers to Cropping System Diversification}

\author{
David A. Mortensen ${ }^{1 \star \dagger}$ and Richard G. Smith ${ }^{2 \dagger}$ \\ ${ }^{1}$ Department of Agriculture, Nutrition, and Food Systems, University of New Hampshire, Durham, NH, United States, \\ ${ }^{2}$ Department of Natural Resources and the Environment, University of New Hampshire, Durham, NH, United States
}

There is no shortage of data demonstrating that diversified cropping systems can sustain high levels of productivity with fewer external inputs and lower externalities compared to more simplified systems. Similarly, data exist indicating diverse cropping systems have greater capacity to buffer against and adapt to weather extremes associated with climate change. Yet, agriculture in the US Corn Belt and other major crop production regions around the world continues to move toward simplified rotations grown over increasingly large acreages. If our goal is to see more of the agricultural landscape made up of diverse agricultural systems and the ecosystem services they provide, it is critical we understand and creatively address the factors that both give rise to monocultures and reinforce their entrenchment at the exclusion of more diversified alternatives. Using the current state of farming and agriculture policy in the US as a case study, we argue that a pernicious feedback exists in which economic and policy forces incentivize low diversity cropping systems which then become entrenched due, in part, to a lack of research and policy aimed at enabling farming practices that support the diversification of cropping systems at larger spatial scales. We use the recent example of dicamba-resistant crops to illustrate the nature of this pernicious feedback and offer suggestions for creating "virtuous feedbacks" aimed at achieving a more diversified agriculture.

Keywords: agrichemical industry, cover crops, crop rotation, ecosystem services, herbicide resistance, policy, glyphosate

\section{INTRODUCTION}

Farmers have known for millennia that planting the same crop in the same field year after year quickly leads to impoverished soil and unmanageable populations of disease organisms, weeds, and insect pests (Bullock, 1992; Howieson et al., 2000; Karlen et al., 2006). Similarly, recent studies have demonstrated that increasing the diversity of a simple crop rotation by even a few crops can result in not only similar or greater overall crop productivity and economic returns compared to the conventional rotation, but also improved soil fertility and lower pest populations and lower requirements for fertilizer and pesticide inputs (Smith et al., 2008, 2018; Davis et al., 2012; Weisberger et al., 2019; Archer et al., 2020). What is more, numerous studies have shown that the ecosystem services that arise from diversifying crop rotations, such as soil quality and fertility enhancements, can also help buffer these systems against weather variability associated with climate change (Bommarco et al., 2013; Gaudin et al., 2015; Williams et al., 2016; Bowles et al., 2020). And recent socio-ecological research suggests that some farmers practicing monoculture acknowledge the role that cropping system diversification can play in adapting to climate change (Roesch-McNally et al., 2018). 
Given the evidence for improvements in productivity, economic outcomes, climate resilience, and other ecosystem services associated with diversified crop rotations, how is it that farmers continue to maintain vast near monocultures of corn and soybean in the US Midwest or wheat in southern Canada and Western Australia, for example? And why would they seemingly choose to farm this way when the benefits of maintaining diverse crop rotations are so well-understood, even among farmers practicing monoculture production?

The answer to the first question is relatively simple. Farmers can successfully grow crops in monocultures and simple crop rotations because they have access to synthetic fertilizers and pesticides. Indeed, without inputs of synthetic fertilizer and pesticides, continuous crop monocultures could not exist. This reliance on fertilizer and pesticides also explains, in large part, why monoculture farming is so fraught from an environmental pollution perspective (Robertson and Swinton, 2005). Often, the synthetic fertilizer that is necessary to drive monoculture production is not taken up by the crop or stored in soil organic matter, meaning some portion of the fertilizer remains in the soil and is therefore susceptible to loss and movement to other ecosystems (Robertson and Vitousek, 2009). Similarly, the pesticides which are required to control otherwise untenable pest levels rarely remain confined to their intended targets (Kolpin et al., 1998; Humann-Guilleminot et al., 2019).

Of course, this simple proximate explanation for the existence of monocultures does not fully acknowledge the critical role the agrichemical industry plays in supporting monoculture production. Indeed, the easy access to fertilizers and pesticides farmers require in order to maintain simple crop rotations would be impossible without an agrichemical industry eager to supply these inputs. Conversely, the agrichemical industry's business model (true of most business models that require keeping shareholders appeased) depends on the production and sale of as much product as possible, while at the same time defending against threats to its market share (Magdoff et al., 2000; Mascarenhas and Busch, 2006; Hendrickson, 2015; Harker et al., 2017). Hence, it might be just as accurate to say monocultures exist because there is an agrichemical industry that profits from their existence.

Now that we've established how it is possible for farmers to farm in monoculture, the second question is why do they choose to do so given the issues described above? The answer to this question is more complex. Many potentially interacting factors contribute to a farmer's decision to specialize in just one or a few crops. We term these factors "simplification forces" because the net result is often a simplified crop rotation. While much of the initial decision process is under farmer control-meaning that in some sense farmers do indeed choose to implement simplified cropping systems-at some point farmers can become locked-in to the simplified system due to factors that act to reinforce the continued existence of the simplified system (e.g., Geels, 2011). These reinforcing factors make it extremely difficult for farmers, once locked-in to a simplified system, to change their practices and/or integrate additional types of crops or cropping practices into their systems. We more fully describe these factors below, with special attention to the reinforcing factors which make cropping system rediversification such a challenge.

\section{SIMPLIFICATION FORCES}

Simplification forces incentivize reducing the diversity of a cropping system. At their foundation, most of these simplification forces have an economic, and hence, political basis (MacDonald et al., 2013). A dearth of competitive markets for alternative crops and a lack of infrastructure for processing and/or product storage limit the types of crops that farmers consider profitable in a given region (Bradshaw et al., 2004; Meynard et al., 2018; Roesch-McNally et al., 2018). Simplification is accelerated when volume discounts are offered for the prevailing commodity crop and associated inputs (Magdoff et al., 2000). In addition, the decoupling of crop and livestock production in many regions has led to farmers specializing in annual row crops, forgoing the perennial pasture crops that were once more common components of their rotations (Howieson et al., 2000; Karlen et al., 2006; Davis et al., 2012; Roesch-McNally et al., 2018). The climate, through its effects on the economics of farming, can also act as a simplification force, simply by limiting the types and scale of crops that can be profitably grown, when they can be planted and harvested, and their yield potentials (Bradshaw et al., 2004). National agriculture policies that have commoditized certain crops or that externalize risks associated with simplified cropping systems provide additional financial incentives, through subsidies and federal crop insurance programs, to grow only those crops (O’Donoghue et al., 2009; Iles and Marsh, 2012; Roesch-McNally et al., 2018). For example, the majority of commodity payments in the US go to just seven crops, while farmers growing certain other types of crops, such as vegetables, nuts, and fruits, often receive little in the way of federal subsidies or other incentives (Iles and Marsh, 2012). Emergence of new policy and subsidiary markets for the products (or byproducts) of the dominant monocrop can also incentivize cropping system simplification, even in systems that are already highly simplified (Karlen et al., 2006). The increase in corn production and concomitant reduction in landscape scale crop diversity that occurred in the US Corn Belt as a consequence of the 2007 Energy Independence and Security Act (i.e., "ethanol mandate"; Rahall, 2007) is a good example of this phenomenon (Landis et al., 2008). Additionally, the fact that externalities associated with monoculture cropping, such as environmental pollution and loss of biocontrol ecosystem services, are typically not borne by the farmer, and therefore not passed on to the consumer, further disincentivizes adoption of more complex cropping systems (Robertson and Swinton, 2005; Landis et al., 2008).

Concomitant with the simplification of cropping systems, many agricultural regions have seen tremendous increases in the size of individual farm operations (MacDonald et al., 2013). In the US for example, while small and medium-sized farms (i.e., farms with 1-404 ha of harvested cropland) make up the overwhelming majority of farms on a number basis, large-scale farms (i.e., those with $>405$ ha of harvested cropland) account for 
over $67 \%$ of the total harvested cropland (Figure 1; USDA NASS, 2019). Many of the same broad simplification forces described above-including disassociation of livestock and crop farming, federal policy decisions, and innovations in labor-saving practices and technology-have, along with economies of size, contributed to the increasing scale and profitability of simple farming systems (Duffy, 2009; Geels, 2011; MacDonald et al., 2013; Hoppe, 2014). At the same time, investments in technology and specialized equipment, including large-scale machinery such as tractors, planters, and sprayers which enable large-acreage farming, can also act to lock farmers into their existing cropping systems.

\section{REINFORCING FACTORS, SOCIO-TECHNOLOGICAL LOCK-IN, AND DEFENSIVE SIMPLIFICATION}

As we've alluded to, some of the simplification forces described above may also become reinforcing factors if they also strongly inhibit farmers' abilities to subsequently change their farming practices-a situation known as "lock-in." Lock-in is the inability of a farmer to deviate from or change the existing farming practice or system due to social, political, economic, or technological reasons (Arthur, 1989; Wilson and Tisdell, 2001; Geels, 2011; Magrini et al., 2016; Wigboldus et al., 2016). The large-scale and specialized equipment purchased to facilitate the growing of crops over extremely large farm acreages represents one type of reinforcing factor because it also makes it difficult or impossible to integrate additional crops into a rotation if those crops would require different equipment for planting or harvesting (Geels, 2011). The erosion of specialized knowledge, skills, and experience necessary to grow and manage a diversity of crops, as well as a lack of farm workers able and willing to do the work, can all be significant reinforcing factors (Iles and Marsh, 2012; Carlisle et al., 2019). Finally, reliance on fertilizers and pesticides can also be reinforcing factors leading to lock-in (e.g., pesticide and technology "treadmills"; Wilson and Tisdell, 2001; Mortensen et al., 2012; Wigboldus et al., 2016).

Beyond locking farmers into specific cropping systems, some especially pernicious reinforcing factors can threaten the ability of other farming systems to coexist within the landscape. These factors tend to be byproducts of the enablers of cropping system simplification, specifically the crop protection products that are relied upon to control weeds and insect pests in simplified cropping systems. These types of reinforcing factors are particularly problematic because they have the potential to reduce landscape-scale crop diversity either by threatening the coexistence of certain crops or cropping systems or by forcing farmers to further simplify their cropping systems as a defensive counter-measure. As an illustrative example, the remainder

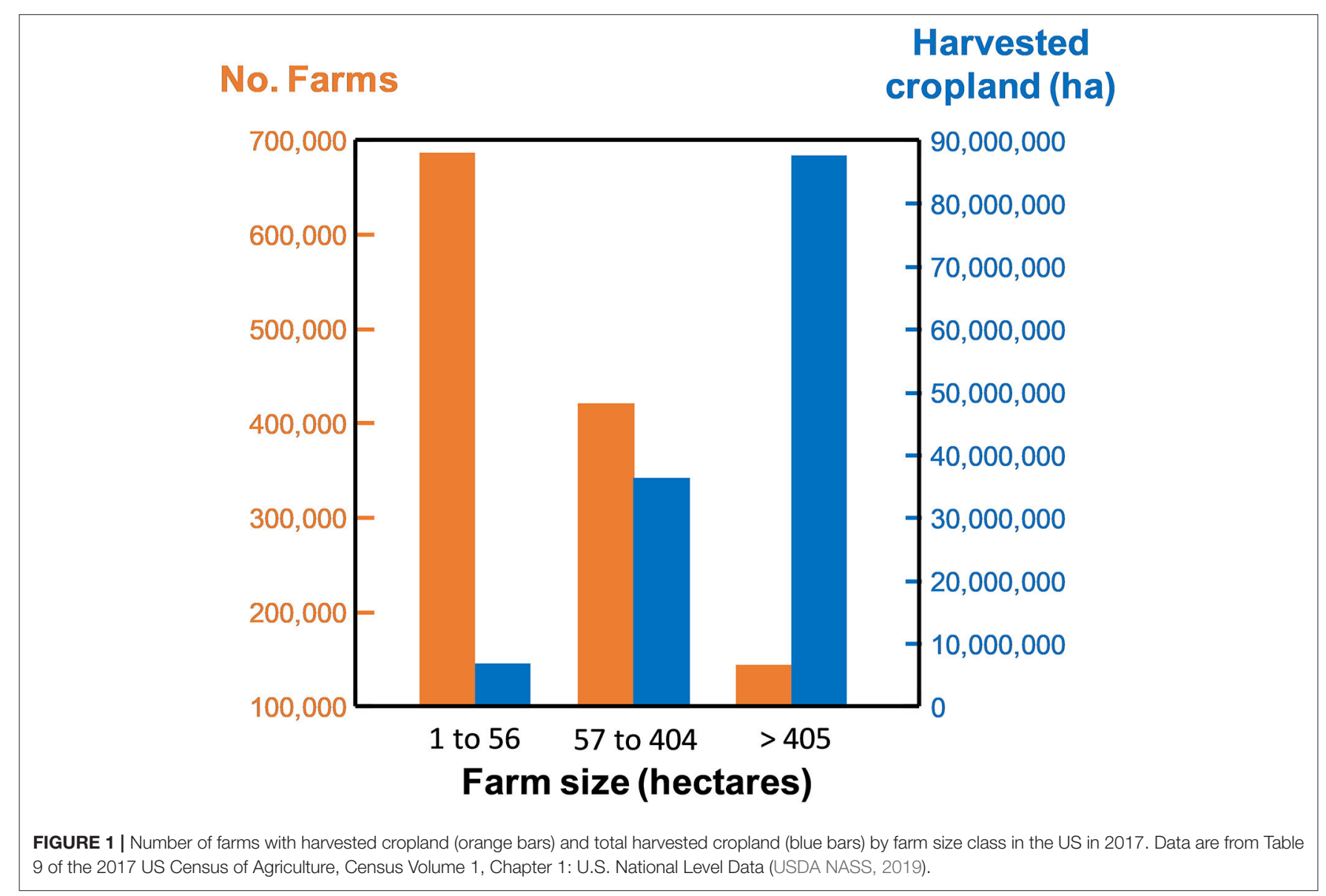


of this section describes one such reinforcing factor: the use of herbicides with high potential to cause drift damage and the recently developed genetically-modified herbicide-resistant crops that have greatly expanded their use.

\section{The Case of Dicamba-Resistant Crops}

Herbicide-resistant crops, crop plants genetically engineered to be resistant to herbicides that would normally kill them, first came to the US market in the mid-1990s. These crops were engineered to be resistant to the herbicide glyphosate, a highly effective broad-spectrum herbicide that is phytotoxically active on a large number of weed and crop species across a wide range of taxa (Duke and Powles, 2009). Modified to express enzymes that are insensitive to or can metabolize glyphosate, glyphosate resistant (GR) crops allowed farmers to easily apply glyphosate in soybean, corn, cotton, canola, sugarbeet, and alfalfa to control weeds without harming the crop (Behrens et al., 2007). With Monsanto (now Bayer) holding the patent on the resistant genes and who first developed glyphosate herbicide, the resulting seed and pesticide package was heavily marketed and then adopted at an unprecedented rate by growers who were attracted to the flexibility and simplicity of the glyphosate/glyphosate resistant crop technology package (Mascarenhas and Busch, 2006; Mortensen et al., 2012).

This commodity seed and pesticide package became a strong reinforcing factor soon after emerging on the market in 1996, and by 2000 , GR soybeans accounted for $54 \%$ of US soybean hectares (Duke and Powles, 2009). By 2018, GR crops were grown on 90,91 , and $94 \%$ of the US corn, cotton, and soybean hectares, respectively (Wechsler, 2018). The technology is effective and easy-to-use and farmers have often responded to these benefits by exclusively planting GR cultivars and applying glyphosate herbicide in the same fields, year after year (Duke and Powles, 2009; National Research Council, 2010).

This single-tactic approach to weed management practiced on over $90 \%$ of the principle commodity crops in the US has resulted in an unintended, but not unexpected, problem: a dramatic rise in the number and extent of weed species resistant to glyphosate (Heap, 2020) and a concomitant decline in the effectiveness of glyphosate as a weed management tool (Duke and Powles, 2009; National Research Council, 2010). As the area planted to GR crops increased, the total amount of glyphosate applied also kept pace, creating intense selection pressure for the evolution of weeds resistant to glyphosate. To be clear, this dramatic increase in glyphosate use would not have been possible without GR crop biotechnology. The number and extent of weed species resistant to glyphosate has increased rapidly since 1996, with 48 species now confirmed globally (Heap, 2020). While several of these species first appeared in cropping systems where glyphosate was being used without a resistant cultivar, the most severe outbreaks have occurred in regions where GR crops have facilitated continued overreliance on this herbicide (Evans et al., 2016).

To address the problem of GR weeds, the seed and agrichemical industries aggressively developed and marketed new genetically engineered cultivars of soybean, cotton and corn, where in addition to glyphosate resistance, additional herbicide resistance traits were added. For reasons that make little sense other than they control a number of the weeds that have evolved resistance, these "next generation" herbicide resistant crops were engineered to also be resistant to older and more environmentally problematic herbicides dicamba (BASF, Monsanto/Bayer) and 2,4-D (Dow AgroSciences) (Behrens et al., 2007; Wright et al., 2010). Unfortunately, while these herbicides can be used to provide some level of control to the weeds that evolved resistance to glyphosate, they are also highly active and strongly phytotoxic to most other broadleaf plants, including crops, and, most problematically, are well-known to be highly drift prone (Egan et al., 2014). Together, these two properties of the new herbicide-resistant crops mean there is a high likelihood of severe damage to broadleaf crop and non-crop plants in nearby fields (Mortensen et al., 2012). In other words, the extent and impact of the non-target effects of using herbicides like dicamba and 2,4-D are large, with equally large potential to result in defensive simplification.

The adverse effects of dicamba use that had been predicted by models and extrapolations from experimental work (Egan et al., 2011; Egan and Mortensen, 2012) have played out in the field. In 2016, the year of their commercial release, dicambaresistant crops were planted on 25 million acres. Acreage doubled to 50 million acres in the 2018 field season and an estimated 60 million acres were planted to these crops in 2019 (Unglesbee, 2019; Wechsler et al., 2019). As a consequence of the problematic properties of dicamba, in the 2017 field season, 3.6 million acres of non-transformed soybean were injured by dicamba drift (Nandula, 2019). This extent of crop injury in response to this crop and herbicide use practice is unprecedented. It is also a significant under representation of the total plant injury that occurred. Importantly, the 3.6 million acres only accounts for injury to soybean and doesn't include other susceptible broadleaf crops nor does it include non-crop broadleaf flowering plants. The dicamba drift issue has been so bad, in fact, that some farmers have been forced to purchase and plant the dicamba-resistant crops defensively, in order to minimize the potential of dicamba drift from neighboring farms injuring their own crops (Wechsler et al., 2019; Fletcher, 2020).

We attempt to capture the spatial and temporal dynamics of such a cropping system practice on landscape level crop diversity in Figure 2. The simple simulation represents an agricultural landscape comprised of 30 individual fields where early in the time course, one field uses the newly transformed crop/herbicide package. The use of the package results in neighboring farmers adopting the practice because retailers shift to limiting seed choices and because package developers provide incentives for "defensive planting," a practice where farmers reduce their risk of crop damage by planting transformed crops that are not susceptible to the non-target effects. Over the course of the 5 year time period, the Shannon diversity index quantifying landscape scale crop diversity falls as does the proportion of the landscape planted to the non-transformed crop.

We contend that the dicamba-resistant cropping system example highlights a central crux of the cropping system diversity problem (Figure 3). In this case, private sector interests (i.e., the biotech seed and agrichemical industry) profit from the 


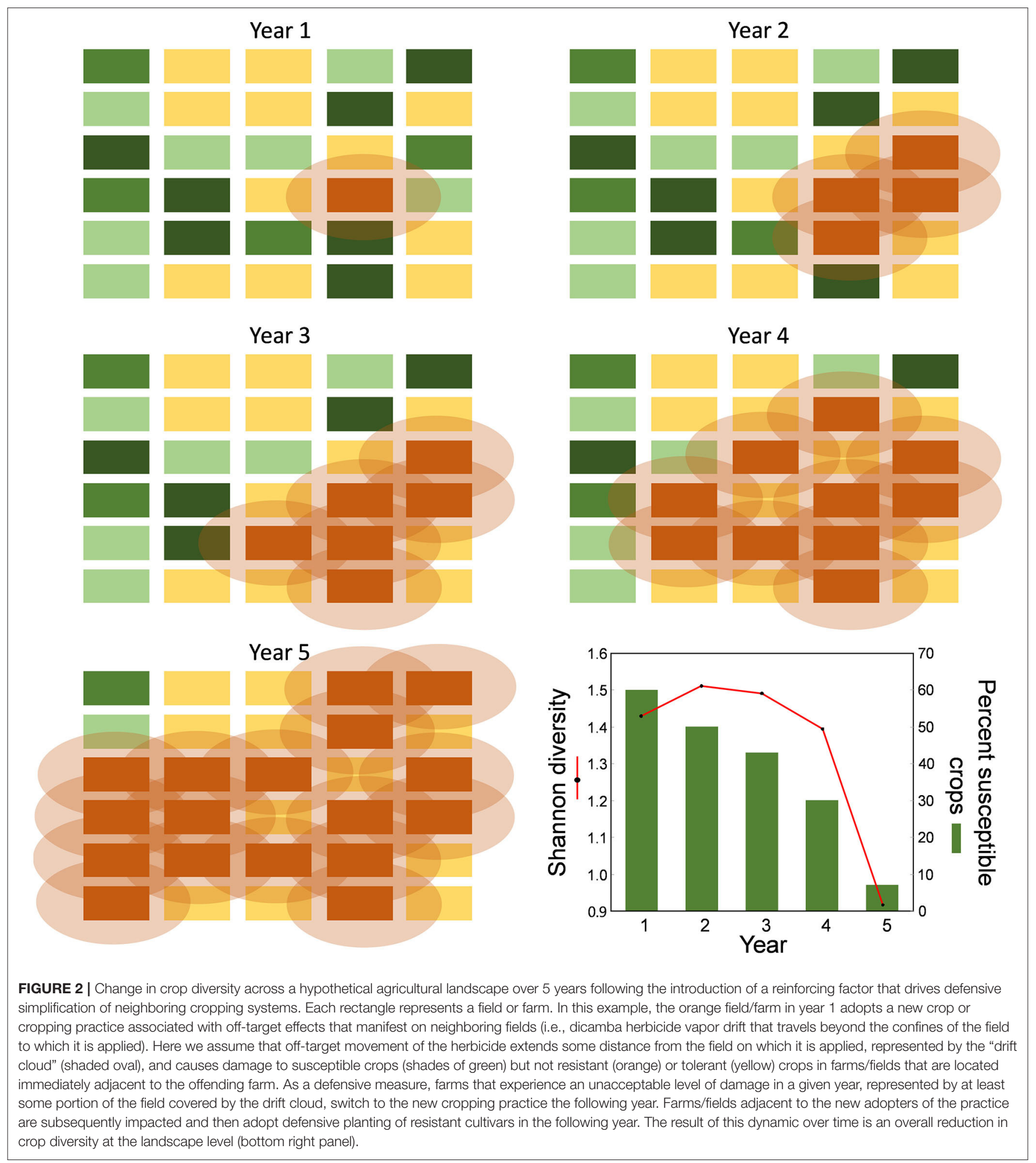

agrichemical inputs and the associated "enabling technologies" that are required to maintain a specific farming system-i.e., large-scale, simplified crop rotations. The larger the scale, and the simpler and more widespread the farming system becomes, the more the industry's product packages are required, and the more the industry profits (Hendrickson, 2015; Clapp, 2018). And as weve stated above, the larger and more simplified the farming system becomes the more farmers become locked-in to the simplified system (Levins and Cochrane, 1996). At the same time, federal agriculture agencies, such as the USDA, invest in 


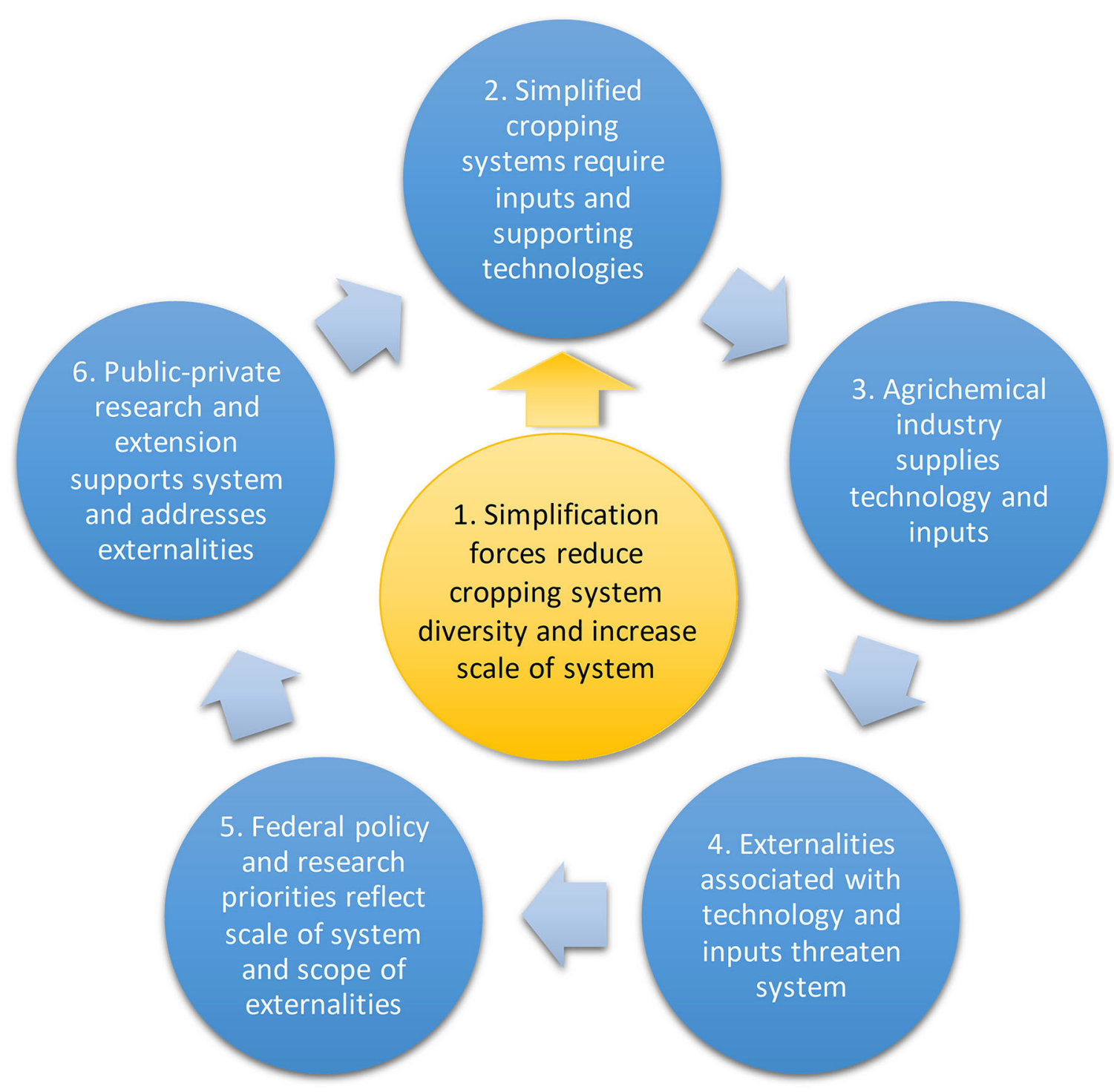

FIGURE 3 | The crux of the cropping system diversification problem: feedbacks that reinforce cropping system simplification. We argue that steps 5 and 6 are where efforts could be made to break the cycle of simplification and encourage cropping system diversification at larger scales.

the system because it is so large-scale. Consequently, agencyfunded research is aimed primarily at addressing inefficiencies of the system, along with the problems that arise because of the system, rather than seeking viable alternative systems (DeLonge et al., 2016; Miles et al., 2017). In so doing, the agencies' research funding priorities support the maintenance of this system. This focus on solving the problems that arise from the system also helps to facilitate partnerships between the same private sector industry that profits from the maintenance of the system and the public sector researchers and extension educators who understandably want to serve their farmer-stakeholders, many of whom are locked-in to the system. These private-public partnerships ultimately benefit the private sector by helping to reinforce the simplified system (Hendrickson, 2015). They can also reinforce the system by locking out competing innovations that would serve to diversify the system if those innovations do not have the support of private interests (Vanloqueren and Baret, 2009).

An assumption implicit in all of this is there must necessarily be a tradeoff between the scale of a farming system and its diversity. In other words, we tend to assume that large scale cropping systems must inherently be simple/low diversity and therefore heavily reliant on external agrichemical inputs with their concomitant externalities, ecosystem disservices, and sustainability challenges. The validity of this assumption is critical given the enormous footprint, both spatially and environmentally, that large scale farming systems have across the agricultural landscape (Figure 1). But is there a biological 
or ecological principle that specifically supports this assumption? The only principles that seem to support the tradeoff that we are aware of appear largely economic (Magdoff et al., 2000). If this is indeed the case, it suggests that current barriers to cropping system diversification might be overcome through actions at the federal policy level; actions that would prioritize cropping system diversification at large scales and catalyze research aimed at scaling up diversified farming systems and the practices and enabling technologies that would support them (Wigboldus et al., 2016; Miles et al., 2017). Our final section outlines a possible roadmap for achieving such actions.

\section{A ROADMAP FOR OVERCOMING BARRIERS TO CROPPING SYSTEM DIVERSIFICATION}

Our aim with this final section of the paper is to convey what it is we see as most needed by policy makers, agriculture scientists, food systems advocates, and other agriculture professionals in order to move agriculture writ large toward greater diversification specifically, and more broadly, an agriculture informed by our expanding knowledge of ecological functions and services. To that end, we see three broad strategies for achieving this objective and discuss each below. Our primary intent is not to provide a step-by-step plan for enabling each strategy, but rather shine a light on each with the hope that others will take the torch and illuminate a clearer and more productive way forward.

\section{Agriculture Scientists Must Enhance the Scope and Scale of Systems-Level Research}

We recognize that systems research is needed to elucidate field and landscape scale properties that underpin long-term delivery of ecological function and services (Kleijn et al., 2019). However, ecologically informed systems research alone will be insufficient to bring about enhancements in cropping system diversification at scales large enough to be beneficially impactful if the products of that research are perceived as only being relevant for smallerscale farming systems (Wigboldus et al., 2016). Conversely, agroecologists and other agriculture scientists who are unwilling to engage in research that addresses the dominant large-scale agricultural systems are likely missing opportunities to make potentially impactful contributions to meaningfully address agriculture's larger environmental footprint. For example, there has been much agroecological research conducted on cover crops for use in smaller-scale and organic cropping systems. Consequently, in organic agriculture cover crops are required on all annually cropped acres, resulting in very high levels of adoption of the practice on certified organic farms. However, the fact that only $1-2 \%$ of US farmland is managed organically means the aggregate effects of this particular cropping system diversification practice on ecosystem function and services at larger landscape scales is limited. What is more, because cover crop adoption on the other $98 \%$ of US farmland managed conventionally is low, ranging from 1 to $3 \%$ (Hamilton et al.,
2017), the greater benefits to society that this practice could generate are, at present, largely unrealized.

Given that the majority of harvested cropland is in largescale farms (Figure 1), research aimed at increasing cropping system diversification must involve identifying diversification strategies that can be demonstrated to work at these larger scales. What are the barriers to cover crop adoption on the other $98 \%$ of conventionally managed US farmland and how can these be overcome? What other strategies to cropping system diversification could apply to, and likely be adopted by, large farm systems and how could these be implemented? What federal economic policy mechanisms could be enacted or changed to facilitate cropping system diversification on large farming systems rather than incentivizing these same farms to maintain simplified systems? How do we close yield gaps in organic cropping systems and scale these systems up without simplification? These are some of the types of questions more agroecologists, in collaboration with rural sociologists and economists, should be asking. In order to enable more agricultural scientists to ask these types of questions, federal agricultural research funding priorities could place greater emphasis on research aimed at identifying holistic production systems where the systems and components of those systems are scalable to the extent possible (Miles et al., 2017). This leads to our second strategy.

\section{Publicly Funded Research Should Address the Common Good, Rather Than Prop Up Unsustainable Systems}

Many of the simplification forces described in the previous sections are the direct or indirect result of policies established by our federal agriculture agencies. Paradoxically, these same federal agencies also direct our public investment in agricultural research. The result is a national agriculture policy agenda that not only incentivizes, but often promotes, large-scale, lowdiversity cropping systems and a national research agenda where much of the funded research addresses problems associated with large-scale, low-diversity cropping systems (Davis et al., 2009; Miles et al., 2017). This does little to serve the common good. We need look no further than the case study detailed in this paper to support this argument. Hence, problems associated with large scale, simplified cropping systems, like herbicide resistance and environmental pollution, will continue to drive the research agendas of agriculture scientists until there are changes to either federal policy or the national research agenda (Davis et al., 2009; Harker et al., 2017; Miles et al., 2017).

We argue that the federal research agenda needs to prioritize cropping system diversification at all scales. Similarly, while productivity of all farms will need to continue to rise over the coming decades, there will also need to be a disproportionate focus placed on improving the long-term sustainability and environmental footprint of farming, and this clearly must include large-scale farms (Hunter et al., 2017). Further, we recognize the capacity for such research to bring about changes in practices on the ground will be much greater with farmers engaged in the research process (Rosmann, 1994; Hassanein, 1999; van de Fliert 
and Braun, 2002). Such participatory methods are proving to be particularly effective at identifying suites of context-dependent agroecological practices that are effective and manageable at farm scales (Blesh and Wolf, 2014; White et al., 2017).

Land-grant institutions will also need to play a role in better serving the common good. When funding comes directly from agrichemical companies to public sector agricultural scientists or extension personnel, there is a strong incentive to focus the research on the issues that the company's products address (Davis et al., 2009; Harker et al., 2017). If these issues are the result of cropping system simplification itself, such as the rise in glyphosate-resistant weeds owing the overuse of glyphosate in GR cropping systems, the resulting research and extension is likely to further entrench the simplified cropping system rather than lead to alternatives to the system (Figure 3). A disproportionately large amount of land grant research has been aimed at propping up unsustainable cropping systems, and for too long these institutions have served as the research and marketing arms of the seed and agrichemical companies (Magdoff et al., 2000). Reducing the influence agrichemical companies have on land grant research and extension programs would likely open a much larger range of potential solutions, beyond just those in which private firms have an interest (Vanloqueren and Baret, 2009).

\section{Agricultural Scientists Must Engage in Policy and Rule-Setting}

Scientists need to engage in the process of rule-setting. Rule-setting that regulates agricultural practices or that incentivizes practices through a variety of regulatory or economic mechanisms (MacDonald et al., 2013) is fraught with economically motivated conflicts of interest biased to support a larger, vertically integrated and more simplified agriculture. It should be the role of the scientist to translate their work in a way that informs ecologically based decision-making. In the absence of this type of decision-making, private sector interests will offer a production-oriented justification that argues for simplification and vertical integration and where little attention is paid to the externalities of production (Harker et al., 2017). The voice of the scientist in this process is largely absent, or when it is invoked, is usually that of a neutral arbiter. Scientists are often called on to present or interpret data when policy makers advance to rule-setting. What is needed is something more than a presentation of the data; what is needed are interpretations of the root cause of problems of an overly simplified agriculture and a decision process that empowers scientists to measure or project the externalities of production practices that enable a more ecologically-weighted policy making. Much has been written about this potential role for scientists (Hoppe, 1999; Crouzat et al., 2018; Sarkki et al., 2020). Are they neutral arbiters, honest brokers, or issue advocates? We argue that agroecologists and other agricultural scientists have largely limited their role to that of the neutral arbiter and therefore have blunted their ability to shift agriculture toward one that places greater value on lessening its environmental impact through such practices as increased crop diversification.

\section{CONCLUSIONS}

The agroecology literature is replete with papers expounding the benefits of cropping system diversification and the necessary role that crop diversity plays in facilitating a more sustainable system of agriculture (e.g., Altieri, 1999; Lin, 2011; Bommarco et al., 2013; and many more), including broad brush calls for "agroecological transformation of monocultures" as "a strategy that represents a robust path to increasing the productivity, sustainability, and resilience of agricultural production" (Altieri et al., 2015). Similarly, recent research indicates many monoculture farmers do recognize the potential agroecological value that diversifying their cropping systems would hold for them in terms of their ability to deal with climate change and that they would like to implement diversification strategies if possible (Roesch-McNally et al., 2018). However, being willing to do something and being able to do something are two very different things. As we hope we have made clear, many farmers are effectively locked-in to their simplified cropping systems due to a variety of factors, some of which are in their control but many of which are largely outside of their control. Addressing these factors head on is likely the only way that cropping system diversification will occur on scales large enough to have meaningful beneficial environmental impacts. We have outlined several strategies, aimed primarily at agricultural scientists and their research funders, for addressing these issues, including expanding the agroecology research agenda to include large-scale farming systems and the search for scalable practices that can actually be integrated into large farms, as well as encouraging agricultural scientists to take a more participatory approach to policy and rule-setting; however, many other strategies likely exist. In that vein, a major potential mechanism for overcoming diversification barriers that we have not touched upon is the power of consumers to directly influence how crops are grown. There are a range of potential actions within this realm, from certification of biodiversity-friendly agriculture to radical reorganization of supply chains, highlighting the need for greater collaboration between the natural and social sciences (e.g., Robertson and Swinton, 2005; Salliou et al., 2019; Valencia et al., 2019). Lastly, federal policy and research funding should be redirected toward incentivizing cropping system diversification and away from initiatives that support unsustainable cropping systems. While our lens on these strategies is from the perspective of the state of farming and policy in the US, it is important to note that these same issues are being addressed and debated elsewhere, with varying degrees of success (e.g., Pe'er et al., 2019). It is likely that the outcomes of these efforts, many of which are occurring within governance systems that differ from those in the US, will provide additional examples for how limited public resources can be invested into agricultural practices that more effectively support the public good.

\section{AUTHOR CONTRIBUTIONS}

All authors contributed to the article and approved the submitted version. 


\section{FUNDING}

This work was funded, in part, by USDA NIFA AFRI Grant No. 2017-67013-26594. Partial funding was provided by the

\section{REFERENCES}

Altieri, M. A. (1999). The ecological role of biodiversity in agroecosystems. Agric. Ecosyst. Environ. 74, 19-31. doi: 10.1016/S0167-8809(99)00028-6

Altieri, M. A., Nicholls, C. I., Henao, A., and Lana, M. A. (2015). Agroecology and the design of climate change-resilient farming systems. Agron. Sustain. Dev. 35, 869-890. doi: 10.1007/s13593-015-0285-2

Archer, D. W., Liebig, M. A., Tanaka, D. L., and Pokharel, K. P. (2020). Crop diversity effects on productivity and economics: a Northern Great Plains case study. Renew. Agric. Food Syst. 35, 69-76. doi: 10.1017/S17421705180 00261

Arthur, B. (1989). Competing technologies, increasing returns, and lock-in by historical events. Econ. J. 99, 116-131. doi: 10.2307/2234208

Behrens, M. R., Mutlu, N., Chakraborty, S., Dumitru, R., Jiang, W. Z., LaVallee, B. J., et al. (2007). Dicamba resistance: enlarging and preserving biotechnology-based weed management strategies. Science 316, 1185-1188. doi: 10.1126/science.1141596

Blesh, J., and Wolf, S. A. (2014). Transitions to agroecological farming systems in the Mississippi river basin: toward an integrated socioecological analysis. Agric. Hum. Values 31, 621-635. doi: 10.1007/s10460-014-9517-3

Bommarco, R., Kleijn, D., and Potts, S. G. (2013). Ecological intensification: harnessing ecosystem services for food security. Trends Ecol. Evol. 28, 230-238. doi: $10.1016 /$ j.tree.2012.10.012

Bowles, T. M., Mooshammer, M., Socolar, Y., Calderon, F., Cavigelli, M. A., Culman, S. W., et al. (2020). Long-term evidence shows that crop-rotation diversification increases agricultural resilience to adverse growing conditions in North America. One Earth 2, 284-293. doi: 10.1016/j.oneear.2020.02.007

Bradshaw, B., Dolan, H., and Smit, B. (2004). Farm-level adaptation to climatic variability and change: crop diversification in the Canadian Prairies. Clim. Change 67, 119-141. doi: 10.1007/s10584-004-0710-z

Bullock, D. G. (1992). Crop rotation. Crit. Rev. Plant Sci. 11, 309-326. doi: 10.1080/07352689209382349

Carlisle, L., de Wit, M. M., DeLonge, M. S., Calo, A., Getz, C., Ory, J., et al. (2019). Securing the future of US agriculture: the case for investing in new entry sustainable farmers. Elem. Sci. Anth. 7:17. doi: 10.1525/elementa.356

Clapp, J. (2018). Mega-mergers on the menu: corporate concentration and the politics of sustainability in the global food system. Glob. Environ. Polit. 18, 12-33. doi: 10.1162/glep_a_00454

Crouzat, E., Arpin, I., Brunet, L., Colloff, M. J., Turkelboom, F., and Lavorel, S. (2018). Researchers must be aware of their roles at the interface of ecosystem services science and policy. Ambio 47, 97-105. doi: 10.1007/s13280-017-0939-1

Davis, A. S., C., Hall, M., Jasieniuk, M. A., Locke, E. C., Luschei, D. A., et al. (2009). Weed science research and funding: a call to action. Weed Sci. 57, 442-448. doi: 10.1614/WS-09-020.1

Davis, A. S., Hill, J. D., Chase, C. A., Johanns, A. M., and Liebman, M. (2012). Increasing cropping system diversity balances productivity, profitability and environmental health. PLoS ONE 7:e47149. doi: 10.1371/journal.pone.0047149

DeLonge, M. S., Miles, A., and Carlisle, L. (2016). Investing in the transition to sustainable agriculture. Environ. Sci. Policy 55, 266-273. doi: 10.1016/j.envsci.2015.09.013

Duffy, M. (2009). Economies of size in production agriculture. J. Hunger Environ. Nutr. 4, 375-392. doi: 10.1080/19320240903321292

Duke, S. O., and Powles, S. B. (2009). Glyphosate-resistant crops and weeds: now and in the future. AgBioForum 12, 346-357. Available online at: https://www. agbioforum.org/v12n34/v12n34a10-duke.pdf

Egan, J. F., Barlow, K. B., and Mortensen, D. A. (2014). A meta-analysis on the effects of 2,4-D and dicamba on soybean and cotton. Weed Sci. 62, 193-206. doi: 10.1614/WS-D-13-00025.1

Egan, J. F., Maxwell, B. D., Mortensen, D. A., Ryan, M. R., and Smith, R. G. (2011). 2,4-Dichlorophenoxyacetic acid (2,4-D)-resistant crops and the potential for
New Hampshire Agricultural Experiment Station. This is NHAES contribution No. 2861. This work is supported by the USDA National Institute of Food and Agriculture Hatch Project 1016232.

evolution of 2,4-D-resistant weeds. Proc. Natl. Acad. Sci. U.S.A.108:E37. doi: 10.1073/pnas. 1017414108

Egan, J. F., and Mortensen, D. A. (2012). Quantifying vapor drift of dicamba herbicides applied to soybean. Environ. Toxicol. Chem. 31, 1023-1031. doi: $10.1002 /$ etc. 1778

Evans, J. A., Tranel, P. J., Hager, A. G., Schutte, B., Wu, C., Chatham, L. A., et al. (2016). Managing the evolution of herbicide resistance. Pest Manag. Sci. 72, 74-80. doi: 10.1002/ps.4009

Fletcher, W. (2020). Opinion No. 19-70115: On Petition for Review of an Order of the U.S. Environmental Protection Agency. United States Court of Appeals for the Ninth Circuit. Available online at: https://www.courthousenews.com/wpcontent/uploads/2020/06/Dicamba.pdf (accessed April 21, 2020)

Gaudin, A. C. M., Tolhurst, T. N., Ker, A. P., Janovicek, K., Tortora, C., Martin, R. C., et al. (2015). Increasing crop diversity mitigates weather variations and improves yield stability. PLoS ONE 10:e0113261. doi: 10.1371/journal.pone.0113261

Geels, F. W. (2011). The multi-level perspective on sustainability transitions: responses to seven criticisms. Environ. Innov. Soc. Trans. 1, 24-40. doi: 10.1016/j.eist.2011.02.002

Hamilton, A. V., Mortensen, D. A., and Kammerer Allen, M. (2017). The state of the cover crop nation and how to set realistic future goals for the popular conservation practice. J. Soil Water Conserv. 72, 111A-115A. doi: 10.2489 /jswc.72.5.111A

Harker, K. N., Mallory-Smith, C., Maxwell, B. D., Mortensen, D. A., and Smith, R. G. (2017). Another View. Weed Sci. 65, 203-205. doi: 10.1017/wsc.2016.30

Hassanein, N. (1999). Changing the Way America Farms: Knowledge and Community in the Sustainable Agriculture Movement. (Lincoln, NE: University of Nebraska Press), 218.

Heap, I. (2020). The International Herbicide-Resistant Weed Database. Online. Available online at: www.weedscience.org (accessed April 30, 2020).

Hendrickson, M. K. (2015). Resilience in a concentrated and consolidated food system. J. Environ. Stud. Sci. 5, 418-431. doi: 10.1007/s13412-015-0292-2

Hoppe, R. (1999). Policy analysis, science and politics: from 'speaking truth to power' to 'making sense together'. Sci. Public Policy 26, 201-210. doi: $10.3152 / 147154399781782482$

Hoppe, R. A. (2014). Structure and Finances of U.S. Farms: Family Farm Report, 2014 Edition, EIB-132, U.S. Department of Agriculture, Economic Research Service, December 2014. Available online at: https://www.ers.usda.gov/ webdocs/publications/43913/50364_eib-132.pdf?v=0 (accessed April 21, 2020).

Howieson, J. G., O’Hara, G. W., and Carr, S. J. (2000). Changing roles for legumes in mediterranean agriculture: developments from an Australian perspective. Field Crops Res. 65, 107-122. doi: 10.1016/S0378-4290(99)00081-7

Humann-Guilleminot, S., Binkowski, L. J., Jenni, L., Hilke, G., Glauser, G., and Helfenstein, F. (2019). A nation-wide survey of neonicotinoid insecticides in agricultural land with implications for agri-environmental schemes. J. Appl. Ecol. 56, 1502-1514. doi: 10.1111/1365-2664.13392

Hunter, M. C., Smith, R. G., Schipanski, M. E., Atwood, L. W., and Mortensen, D. A. (2017). Agriculture in 2050: recalibrating targets for sustainable intensification. BioScience 67, 386-391. doi: 10.1093/biosci/bix010

Iles, A., and Marsh, R. (2012). Nurturing diversified farming systems in industrialized countries: how public policy can contribute. Ecol. Soc. 14:42. doi: 10.5751/ES-05041-170442

Karlen, D. L., Hurley, E. G., Andrews, S. S., Cambardella, C. A., Meek, D. W., Duffy, M. D., et al. (2006). Crop rotation effects on soil quality at three northern corn/soybean belt locations. Agron. J. 98, 484-495. doi: 10.2134/agronj2005.0098

Kleijn, D., Bommarco, R., Fijen, T. P. M., Garibaldi, L. A., Potts, S. G., and van der Putten, W. H. (2019). Ecological intensification: bridging the gap between science and practice. Trends Ecol. Evol. 34, 154-166. doi: 10.1016/j.tree.2018.11.002 
Kolpin, D. W., Barbash, J. E., and Gilliom, R. J. (1998). Occurrence of pesticides in shallow groundwater of the United States: initial results from the national water-quality assessment program. Environ. Sci. Tech. 32, 558-566. doi: 10.1021/es970412g

Landis, D. A., Gardiner, M. M., van der Werf, W., and Swinton, S. M. (2008). Increasing corn for biofuel production reduces biocontrol services in agricultural landscapes. Proc. Natl. Acad. Sci.U.S.A. 105, 20552-20557. doi: 10.1073/pnas.0804951106

Levins, R. A., and Cochrane, W. W. (1996). The treadmill revisited. Land Econ. 72, 550-553. doi: 10.2307/3146915

Lin, B. B. (2011). Resilience in agriculture through crop diversification: adaptive management for environmental change. BioScience 61, 183-193. doi: 10.1525/bio.2011.61.3.4

MacDonald, J. M., Korb, P., and Hoppe, R. A. (2013). Farm Size and the Organization of U.S. Crop Farming, ERR-152. U.S. Department of Agriculture, Economic Research Service, August 2013. Available online at: https://www.ers. usda.gov/webdocs/publications/45108/39359_err152.pdf (accessed April 21, 2020).

Magdoff, R., Foster, J. B., and Buttel, F. H. (2000). “An overview," in Hungry for Profit: The Agribusiness Threat to Farmers, Food, and the Environment. eds R. Magdoff, J. B. Foster, and F. H. Buttel (New York, NY: Monthly Review Press), 7-22.

Magrini, M. B., Anton, M., Cholez, C., Corre-Hellou, G., Duc, G., Jeuffroy, M. H., et al. (2016). Why are grain-legumes rarely present in cropping systems despite their environmental and nutritional benefits? Analyzing lock-in in the French agrifood system. Ecol. Econ. 126, 152-162. doi: 10.1016/j.ecolecon.2016. 03.024

Mascarenhas, M., and Busch, L. (2006). Seeds of change: intellectual property rights, genetically modified soybeans and seed saving in the United States. Sociol. Rural. 46, 122-138. doi: 10.1111/j.1467-9523.2006.00406.x

Meynard, J., Charrier, F., Fares, M., Le Bail, M., and Magrini, M., Charlier, et al. (2018). Socio-technical lock-in hinders crop diversification in France. Agron. Sust. Dev. 38:54. doi: 10.1007/s13593-018-0535-1

Miles, A., DeLonge, M. S., and Carlisle, L. (2017). Triggering a positive research and policy feedback cycle to support a transition to agroecology and sustainable food systems. Agroecol. Sust. Food Syst. 41, 855-879. doi: 10.1080/21683565.2017.1331179

Mortensen, D. A., Egan, J. F., Maxwell, B. D., Ryan, M. R., and Smith, R. G. (2012). Navigating a critical juncture for sustainable weed management. BioScience 62, 75-84. doi: 10.1525/bio.2012.62.1.12

Nandula, J. K. (2019). Herbicide resistance traits in maize and soybean: current status and future outlook. Plants 8:337. doi: 10.3390/plants8090337

National Research Council (2010). The Impact of Genetically Engineered Crops on Farm Sustainability in the United States. (Washington, DC: The National Academies Press), 270.

O'Donoghue, E. J., Roberts, M. J., and Key, N. (2009). Did the federal crop insurance reform act alter farm enterprise diversification? J. Agric. Econ. 60, 80-104. doi: 10.1111/j.1477-9552.2008.00166.x

Pe'er, G., Zinngrebe, Y., Moreira, F., Sirami, C., Schindler, S., et al. (2019). A greener path for the EU common agricultural policy. Science 365, 449-451. doi: 10.1126/science.aax3146

Rahall, N. (2007). HR 6.: Energy Independence and Security Act of 2007. Washington, DC: Library of Congress.

Robertson, G. P., and Swinton, S. M. (2005). Reconciling agricultural productivity and environmental integrity: a grand challenge for agriculture. Front. Ecol. Environ. 3, 38-46. doi: 10.1890/1540-9295(2005)003[0038:RAPAEI]2.0.CO;2

Robertson, G. P., and Vitousek, P. M. (2009). Nitrogen in agriculture: balancing the cost of an essential resource. Ann. Rev. Environ. Res. 34, 97-125. doi: 10.1146/annurev.environ.032108.105046

Roesch-McNally, G. E., Arbuckle, J. G., and Tyndall, J. C. (2018). Barriers to implementing climate resilient agricultural strategies: the case of crop diversification in the U.S. Corn Belt. Glob. Environ. Change 48, 206-215. doi: 10.1016/j.gloenvcha.2017.12.002

Rosmann, R. L. (1994). Farmer initiated on-farm research. Am. J. Alternat. Agr. 9, 34-37. doi: 10.1017/S0889189300005531

Salliou, N., Muradian, R., and Barnaud, C. (2019). Governance of ecosystem services in agroecology: when coordination is needed but difficult to achieve. Sustainability 11:1158. doi: 10.3390/su11041158

Sarkki, S., Heikkinen, H. I., Komu, T., Partanen, M., Vanhanen, K., and Lépy, É. (2020). How boundary objects help to perform roles of science arbiter, honest broker, and issue advocate. Sci. Public Policy 47, 161-171. doi: $10.1093 / \mathrm{scipol} / \mathrm{scz} 055$

Smith, E. G., Harker, K. N., O’Donovan, J. T., Turkington, T. K., Blackshaw, R. E., Lupwayi, N. Z., et al. (2018). The profitability of diverse crop rotations and other cultural methods that reduce wild oat (Avena fatua). Can. J. Plant Sci. 98, 1094-1101. doi: 10.1139/cjps-2018-0019

Smith, R. G., Gross, K. L., and Robertson, G. P. (2008). Effects of crop diversity on agroecosystem function: crop yield response. Ecosystems 11, 355-366. doi: 10.1007/s10021-008-9124-5

Unglesbee, E. (2019). Dicamba Déjà vu: regulators brace for another year of dicamba injury, DTN Progressive Farmer, March 6, 2019. Available online at: https://www.dtnpf.com/agriculture/web/ag/crops/article/2019/03/06/stateregulators-brace-another-year-2 (accessed March 6, 2019).

USDA NASS (2019). US Census of Agriculture. Available online at: www.nass.usda. gov/Publications/AgCensus/2017/Full_Report/Volume_1,_Chapter_1_US/

Valencia, V., Wittman, H., and Blesh, J. (2019). Structuring markets for resilient farming systemts. Agron. Sust. Dev. 39:25. doi: 10.1007/s13593-019-0572-4

van de Fliert, E., and Braun, A. R. (2002). Conceptualizing integrative, farmer participatory research for sustainable agriculture: from opportunities to impact. Agric. Hum. Values 19, 25-38. doi: 10.1023/A:1015081030682

Vanloqueren, G., and Baret, P. V. (2009). How agricultural research systems shape a technological regime that develops genetic engineering but locks out agroecological innovations. Res. Policy 38, 971-983. doi: 10.1016/j.respol.2009.02.008

Wechsler, S. J. (2018). Trends in the adoption of genetically engineered corn, cotton, and soybeans. United States Department of Agriculture-Economic Research Service. Available online at: https://www.ers.usda.gov/amber-waves/2018/ december/trends-in-the-adoption-of-genetically-engineered-corn-cottonand-soybeans/ (accessed May 18, 2020)

Wechsler, S. J., Smith, D., McFadden, J., Dodson, L., and Williamson, S. (2019). The use of genetically engineered dicamba-tolerant soybean seeds has increased quickly, benefiting adopters but damaging crops in some fields. United States Department of Agriculture-Economic Research Service. Available online at: https://www.ers.usda.gov/amber-waves/2019/october/the- useof-genetically-engineered-dicamba-tolerant-soybean-seeds-has-increasedquickly-benefiting-adopters-but-damaging-crops-in-some-fields/ (accessed May 18, 2020).

Weisberger, D., Nichols, V., and Liebman, M. (2019). Does diversifying crop rotations suppress weeds? A meta-analysis. PLoS ONE 14:e0219847. doi: 10.1371/journal.pone.0219847

White, C. M., DuPont, S. T., Hautau, M., Hartman, D., Finney, D. M., Bradley, B., et al. (2017). Managing the trade off between nitrogen supply and retention with cover crop mixtures. Agric. Ecosyst. Environ. 237, 121-133. doi: 10.1016/j.agee.2016.12.016

Wigboldus, S., Klerkx, L., Leeuwis, C., Schut, M., Muilerman, S., and Jochemsen, H. (2016). Systemic perspectives on scaling agricultural innovations. A review. Agron. Sustain. Dev. 36:46. doi: 10.1007/s13593-0160380-z

Williams, A., Hunter, M. C., Kammerer, M., Kane, D. A., Jordan, N. R., Mortensen, D. A., et al. (2016). Soil water holding capacity mitigates downside risk and volatility in US rainfed maize: time to invest in soil organic matter? PLoS ONE 11:e0160974. doi: 10.1371/journal.pone.0160974

Wilson, C., and Tisdell, C. (2001). Why farmers continue to use pesticides despite environmental, health and sustainability costs. Ecol. Econ. 39, 449-462. doi: 10.1016/S0921-8009(01)00238-5

Wright, T. R., Shan, G., Walsh, T. A., Lira, J. M., Cui, C., et al. (2010). Robust crop resistance to broadleaf and grass herbicides provided by aryloxyalkanoate dioxygenase transgenes. Proc. Natl. Acad. Sci. 107, 20240-20245. doi: 10.1073/pnas.1013154107

Conflict of Interest: The authors declare that the research was conducted in the absence of any commercial or financial relationships that could be construed as a potential conflict of interest.

Copyright (C) 2020 Mortensen and Smith. This is an open-access article distributed under the terms of the Creative Commons Attribution License (CC BY). The use, distribution or reproduction in other forums is permitted, provided the original author(s) and the copyright owner(s) are credited and that the original publication in this journal is cited, in accordance with accepted academic practice. No use, distribution or reproduction is permitted which does not comply with these terms. 